\title{
Evaluation and Selection of a Medium for the Thermophilic Oxic Process
}

\author{
LIU BAO GANG ${ }^{1}$, SHUJI NODA ${ }^{2}$, ISAO YOSHIDA ${ }^{3}$ and TADAHIRO MORI ${ }^{4}$ \\ ${ }^{1}$ Laboratory of Environmental Biotechnology, Shimane University \\ /1060 Nishikawatus-cho, Matsue-city, Shimane 690, Japan \\ ${ }^{2}$ Institute of Industrial Science and Technology, \\ /105 Izumotyou, Yatukagunn, Shimane 699-01, Japan \\ ${ }^{3}$ Faculty of Agriculture, Tottori University \\ /4-101 Koyama-cho Tottori-city, Tottori 680 , Japan \\ ${ }^{4}$ Institute of Green, Land and Water \\ /1-18-15 Higasiabiko,Abiko city, Chiba 270, Japan
}

\begin{abstract}
A thermophilic oxic process has features that can be applied to treat various kinds of wastewaters which contain high concentrations of SS and BOD, such as swine waste and shochu processing wastewater. Though such wastewaters were treated at high BOD loads, a minute amount of excess sludge was formed. Cedar chips, wood charcoals, activated carbon and kumazasa charcoals were examined by using red bean processing wastewater to find the suitable characteristics as a medium in this process. In order to raise the temperature, the high water holding capacity of material was a necessary condition, since the added wastewater could be absorbed in the medium. The $\mathrm{EP} / \mathrm{W}$ ratio was defined. It equals the ratio of effective pore volume (EP), constructed by the pore of which the diameter was larger than $10 \mu \mathrm{m}$, to water holding capacity (W). The high $\mathrm{EP} / \mathrm{W}$ ratio of material means that this material can be a habitat of bacteria and the wastewater absorbed in the medium can be effectively treated. The equation (moisture content $(\mathrm{w} / \mathrm{v}) \times \mathrm{BOD}(\mathrm{g} / l) \times \mathrm{EP} / \mathrm{W}>4)$ can be applied to primarily select the material as a medium for the thermophilic oxic process.
\end{abstract}

Key Words : high temperature, water holding capacity, pore volume, effective pore volume, $\mathrm{EP} / \mathrm{W}$ ratio, medium of thermophilic oxic process

\section{INTRODUCTION}

A thermophilic oxic process was applied to treat high strength organic wastewaters which contained high concentrations of SS and BOD, for example, the red bean processing wastewater ${ }^{1)}$, the shochu processing wastewater ${ }^{2}$, the swine waste mixed with waste food oil $^{3)}$, or sewage sludge $^{4,5)}$. This process is similar to a composting process when a sludge, of which the moisture content was approximately $80 \%$, was applied from the view of temperature increase ${ }^{6,7)}$. However, this process can be applied not only to treat the sludge as the composting process but also to treat wastewater containing a high concentration of organic matter. The higher the moisture content of the waste, the more difficult the temperature increase becomes 
because the permeability of the air becomes bad and the biological reaction rate decreases $^{8}$. In this process, a medium (for example, cedar chips) was used in order to adjust the moisture content of the mixture (wastewater and medium), to improve the permeability of air, and provide a habitat for bacteria. When the cedar chips were used as the medium and a suitable organic load was applied to the bioreactor, in which the walls were surrounded by insulated materials, the temperature in the reactor could increase automatically by the microorganic heat from room temperature to a temperature higher than $50^{\circ} \mathrm{C}$. In this environmental condition of temperature, a high amount of thermophiles existed in the medium ${ }^{9)}$. By the biological activities, a high BOD load ranged from 3 to $12.5 \mathrm{~kg} \cdot \mathrm{m}^{-3} \cdot \mathrm{d}^{-1}$ could be applied, and the water in the added waste could be all evaporated $^{1,3)}$. The other most interesting characteristic of this process was a formation of a minute amount of excess sludge when the suitable high BOD load was applied ${ }^{9}$. Therefore, it is important to select the correct medium materials for the thermophilic oxic process. In this paper, several kinds of materials were selected based on their water holding capacity and pore volume, and then tested by adding red bean processing wastewater to the thermophilic oxic process in order to evaluate the characteristics of a medium needed for the process from the view of temperature increase, adjusting moisture content and a habitat of bacteria.

\section{MATERIALS AND METHODS}

Wastewater The wastewater examined in the present study was red bean processing wastewater which was sampled from the Konishi red bean processing factory in Matsue, Japan. The sampled wastewater was immediately transported to a laboratory, and kept in a refrigerated room at a temperature of $4^{\circ} \mathrm{C}$.

Medium The materials used as a medium in the thermophilic oxic process were cedar chips which were made by Sanninn Marowa Co.Ltd, wood charcoals and kumazasa charcoals which were made by Tahara Technique Service Co. Ltd, and activated carbon which was made by Takeda Chemical Industries Ltd.. The moisture content of the raw cedar chips was approximately $40 \%(\mathrm{w} / \mathrm{w})$ and it was decreased to approximately $20 \%(\mathrm{w} / \mathrm{w})$ by drying them under the sun for approximately three days before they were put into the reactor. The moisture contents of other materials were lower than $5 \%(\mathrm{w} / \mathrm{w})$ and directly used.

Apparatus The flowchart of the experimental apparatus is shown in Fig. 1. The reactor was a cylindrical container (20 $l$ in effective volume) with a perforated plate at the bottom, surrounded by Styrofoam insulation (200 $\mathrm{mm}$ in thickness). The overall heat transfer coefficient of the reactor was $0.344 \mathrm{kcal} \cdot \mathrm{h}^{-1} \cdot{ }^{\circ} \mathrm{C}^{-1} \cdot \mathrm{m}^{-2}{ }^{2)}$. The medium (20 l) was put into the reactor above the perforated plate in order to absorb the amount of wastewater containing a high concentration of wastes. The perforated plate was made of a thin iron plate which had many holes. The diameter of a hole was 0 . $5 \mathrm{~mm}$ in order to prevent the medium passing through the perforated plate. The temperature was determined using a thermometer which was inserted into the medium at the center of the reactor. It was monitored by the computer (NEC, PC$\mathrm{KD} 55 \mathrm{~K})$ and recorded by the recorder (Chino, RH720-RNN). The reactor was placed on a scale (Tanida, BEC-800) in order to continuously measure the weight of the 


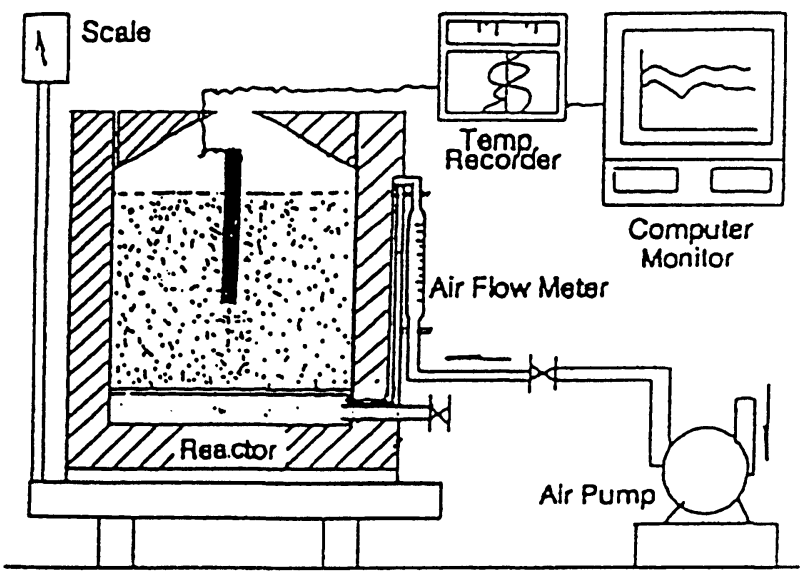

Fig. 1 The flowchart of thermophilic oxic process

medium. Air was supplied by an air compressor (Hitachi, 0.20P-5S) through a air flow meter (ST-10A).

Operation of the Process Four runs were carried out by changing the material as shown in Table 1. At the initial time, raw wastewater and medium were completely mixed by hand outside the reactor, then put into the reactor. Seeding was not necessary because bacteria might come from the air. Wastewater was added to the upper part of the reactor once a day. A lid was used to seal the reactor after the addition of wastewater. Air, the pressure of which was reduced to $0.2 \mathrm{~kg} / \mathrm{cm}^{2}$, was supplied to the reactor. After 23 hours of the addition of the wastewater, draining was carried out for 1 hour. Turning of the medium was necessary. It was conducted by hand every 24 hours $^{11}$. The medium can be continuously used.

Quantity of $\mathrm{CO}_{2}$ evolved The quantity of $\mathrm{CO}_{2}$ in the off-gas was determined from the results of the runs. After putting the wastewater into the reactor, one litre of offgas was immediately sampled in the one litre

Table 1 Experimental conditions

\begin{tabular}{ccccc}
\hline Run No. & 1 & 2 & 3 & 4 \\
\hline Medium & $\begin{array}{c}\text { Cedar } \\
\text { chips }\end{array}$ & $\begin{array}{c}\text { Wood } \\
\text { charcoals }\end{array}$ & $\begin{array}{c}\text { Activated } \\
\text { carbon }\end{array}$ & $\begin{array}{c}\text { Kumazasa } \\
\text { charcoals }\end{array}$ \\
\hline BOD load $\left(\mathrm{kg} \cdot \mathrm{m}^{-3} \cdot \mathrm{d}^{-1}\right)$ & 4 & 4 & 4 & 4 \\
\hline $\begin{array}{c}\text { Added water load } \\
\left(\mathrm{kg} \cdot \mathrm{m}^{-3} \cdot \mathrm{d}^{-1}\right)\end{array}$ & 110 & 110 & 110 & 110 \\
\hline $\begin{array}{c}\text { Aeration rate } \\
\left(l \cdot \mathrm{m}^{-3} \cdot \mathrm{min}^{-1}\right)\end{array}$ & 150 & 150 & 150 & 150 \\
\hline
\end{tabular}


of gas sample bag by the sampling pump (Cole-Parmer, No.7530-40). The samples were taken every one hour until the next addition of the wastewater. The amount of carbon in the off-gas was calculated by multiplying $\mathrm{CO}_{2}$ concentrations by volume of gas excreted out of the reactor. The concentrations of TOC in the influent and effluent were also determined and the $\mathrm{CO}_{2}$ conversion ratio can be calculated.

Analysis The following items were analyzed : moisture content of the medium, COD, BOD and TOC in the influent and effluent, $\mathrm{CO}_{2}$ in off-gas, the water holding capacity and pore volume. The moisture content was determined by weighing approximately 3 grams of a wet sample before and after drying at $105^{\circ} \mathrm{C}$ for 24 hours. The sample for measurement of COD, BOD and TOC of raw wastewater was pretreated by the following methods. Fifty grams of the sample was taken into a homogenizer cup and dispersed at 10,000 rpm for $10 \mathrm{~min}$. with a homogenizer (Type HM-10SA-Nippon Rikagaku Kikai, Co, Ltd.). Then this sample was treated by an ultrasonic disrupter (Type UR-200P, Tomy Seiko, Co, Ltd.) at 6 of the output for 5 min.. Then COD and BOD were determined according to JIS-K-0102. TOC was measured by a TOC analyzer (Type TOC 5000, Shimazu,). The water holding capacity was measured by the water absorbed in $200 \mathrm{~m} l$ of dried material which was immersed in the water for 30 minutes in a $250 \mathrm{ml}$ cylinder with a stopcock at the bottom. The pore volume was measured by a Porosimeter (Carulo Elra Ltd.). The photos were taken by a scanning electron microscope (SEM) (S2100, Hitachi). The photo of the bacteria was taken after serial washing by using different concentrations of an ethylalcohol solution and dried by a $\mathrm{CO}_{2}$ critical point dryer (HCP-2, Hitachi). The concentration of $\mathrm{CO}_{2}$ in the off-gas was measured by gas-chromatography (Shimazu, GC-14A,). The airflow rate was measured by an integrated air flow meter (Shinagawa, WE-1A).

\section{RESULTS AND DISCUSSION}

Temperature increase The temperature increase during two cycles in each run was investigated and the results are shown in Fig. 2. In Runs 1 and 2 , the maximum temperature increased to higher than $60^{\circ} \mathrm{C}$. In Run 4, the maximum temperature increased to approximately $37^{\circ} \mathrm{C}$ and in Run 3 , the temperature was approximately $31^{\circ} \mathrm{C}$ which was a little higher than atmospheric temperature.

Removal efficiencies of BOD, TOC and $\mathrm{CO}_{2}$ conversion ratio The water quality of the raw red bean processing wastewater is shown in Table 2. The removal efficiencies of BOD, TOC in each run are shown in Table 3. In Runs 1 and 2, the temperature increased to higher than $60^{\circ} \mathrm{C}$, and the removal efficiencies of BOD and TOC were higher than $92 \%$. In Run 4 , the temperature increased to approximately $37^{\circ} \mathrm{C}$, and the removal efficiencies of $\mathrm{BOD}$ and $\mathrm{TOC}$ were approximately $75 \%$. In case of Run 3 , the temperature did not increase and the removal efficiencies of $\mathrm{BOD}$ and $\mathrm{TOC}$ were approximately $70 \%$ and this may be the results of absorption and filtration by the activated carbon.

$\mathrm{CO}_{2}$ conversion ratios in the off-gas in Runs 1, 2, 3 and 4 were 95, 96, 51, and $58 \%$, respectively. A high $\mathrm{CO}_{2}$ conversion ratio means that the organic matter was completely decomposed and a minute amount of sludge was formed. From these results, the cedar chips and wood charcoals could be used as the medium in the thermophilic oxic process to treat red bean processing 


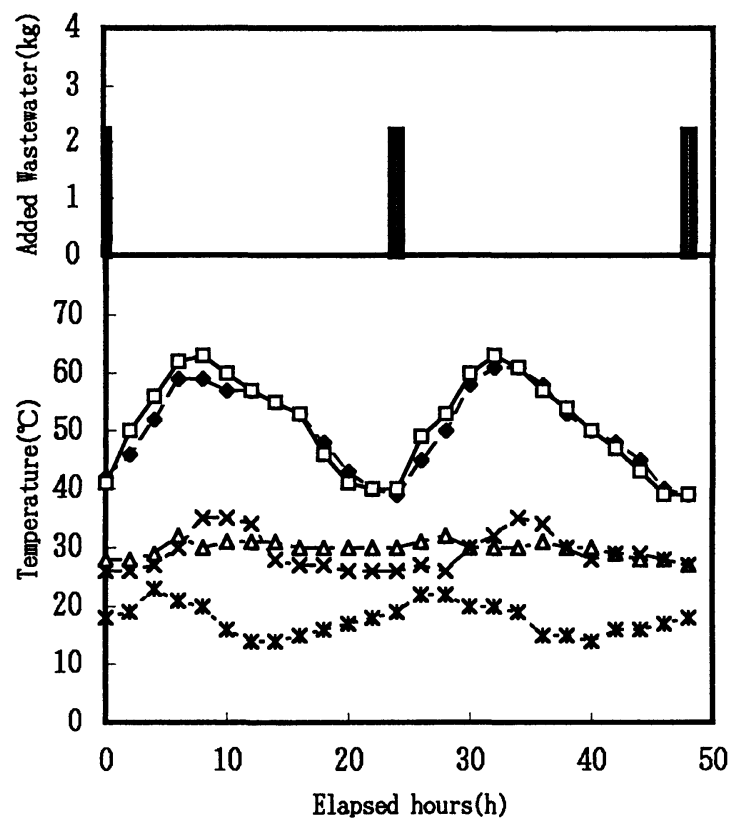

Fig. 2 Changes in temperature by using cedar chips $(\diamond)$, wood charcoals $(\square)$, activated carbon $(\triangle)$, kumazasa charcoals $(X)$, and room temperatrue $(*)$

Table 2 Water quality of wastewater

\begin{tabular}{cc}
\hline Item & Concentration $(\mathrm{mg} / l)$ \\
\hline BOD & 36,000 \\
COD & 25,000 \\
TS & 5,200 \\
VTS & 5,100 \\
SS & 4,200 \\
TOC & 22,000 \\
\hline
\end{tabular}

Table 3 Removal efficiencies of BOD, TOC and $\mathrm{CO}_{2}$ conversion ratios

\begin{tabular}{lcccc}
\hline No. Item & $\begin{array}{c}\text { Cedar } \\
\text { chips }\end{array}$ & $\begin{array}{c}\text { Wood } \\
\text { charcoals }\end{array}$ & $\begin{array}{c}\text { Activated } \\
\text { carbon }\end{array}$ & $\begin{array}{c}\text { Kumazasa } \\
\text { charcoals }\end{array}$ \\
\hline (1) Max. Tem. ( ${ }^{\circ}$ C) & 61 & 65 & 31 & 37 \\
(2) BOD removal efficiency (\%) & 92 & 95 & 70 & 75 \\
\hline (3) TOC removal efficiency (\%) & 95 & 96 & 70 & 76 \\
(4) Carbon in added wastewater (g) & 182.9 & 182.9 & 182.9 & 182.9 \\
\hline (5) Carbon in off-gas (g) & 172.8 & 174.3 & 92.5 & 105.6 \\
\hline (6) $\mathrm{CO}_{2}$ conversion ratio (\%) & 95.5 & 96.3 & 50.6 & 57.7 \\
\hline
\end{tabular}

Note : $\mathrm{CO} 2$ conversion ratio $=(5) /(4)) * 100$ 
wastewater.

Physical properties of materials and $\mathrm{EP} / \mathrm{W}$ ratio The structure of cedar chips, wood charcoals, activated carbon and kumazasa charcoals were observed by the SEM as shown in photos $1,2,3$ and 4. Cedar chips, wood charcoals and kumazasa charcoals had a matrix pore construction but the activated carbon was different. The thickness of wall of the pore of wood charcoals was thicker than that of the cedar chips and it was thinner compared with kumazasa charcoals.

Size, pore volume and water holding capacity of the medium were also investigated. The results are shown in Table 4. The cumulative pore volumes of these materials were measured and the results are

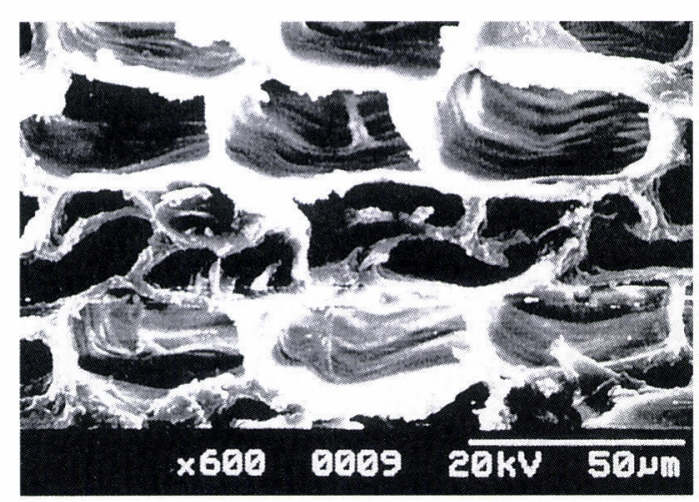

Phot 1 Cedar chips

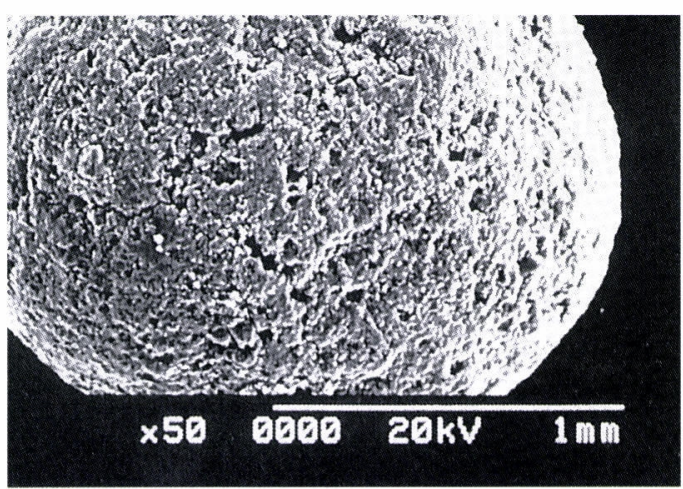

Phot 3 Activated carbon shown in Fig. 3. The pore volume of the cedar chips was the biggest because the wall of the pore was thin as shown in the above SEM photos and it was the smallest in the case of the activated carbon.

The water holding capacity of the cedar chips was the highest of these four media when it was expressed by the usual way, that is, weight per weight, as in the previous papers $^{1,3)}$. It was the lowest in the case of the activated carbon. However, the water holding capacity of the activated carbon expressed by weight per volume was higher than wood charcoals and kumazasa charcoals. Because the volume of the bioreactor was fixed, the water holding capacity expressed by weight per volume should be used to estimate how much water was held in the

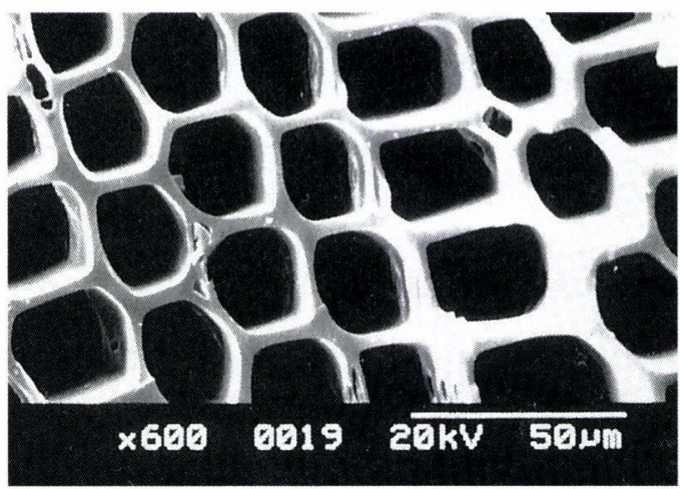

Phot 2 Wood charoal

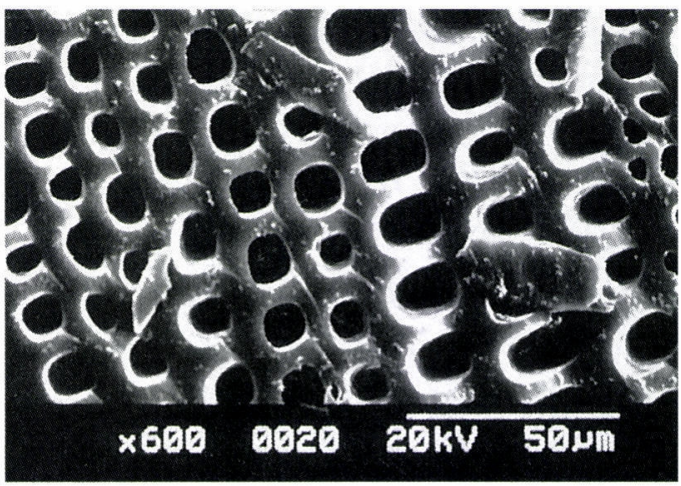

Phot 4 Kumazasa charcoal 
Table 4 Physical properties of media

\begin{tabular}{|c|c|c|c|c|}
\hline Item & $\begin{array}{l}\text { Cedar } \\
\text { chips }\end{array}$ & $\begin{array}{c}\text { Wood } \\
\text { charcoals }\end{array}$ & $\begin{array}{l}\text { Activated } \\
\text { carbon }\end{array}$ & $\begin{array}{c}\text { Kumazasa } \\
\text { charcoals }\end{array}$ \\
\hline Size $(\mathrm{mm})$ & $2-5$ & $1.8-3.2$ & 2 & $2-5$ \\
\hline $\begin{array}{l}\text { Water holding } \\
\text { capacity }(\mathrm{g} / \mathrm{g})\end{array}$ & 2.53 & 1.84 & 0.80 & 1.25 \\
\hline $\begin{array}{l}\text { Water holding } \\
\text { capacity }(\mathrm{g} / \mathrm{m} l)\end{array}$ & 0.329 & 0.276 & 0.288 & 0.241 \\
\hline Filling density $(\mathrm{g} / \mathrm{m} l)$ & 130 & 150 & 360 & 193 \\
\hline Pore volume $(\mathrm{m} l / \mathrm{g})$ & 2.6 & 2.4 & 0.15 & 1.26 \\
\hline $\begin{array}{c}\text { Effective pore } \\
\text { volume (EP) }(\mathrm{m} l / \mathrm{g})\end{array}$ & 1.19 & 1.13 & 0.015 & 0.57 \\
\hline $\begin{array}{l}\text { Ratio of EP to water } \\
\text { holding capacity }(\mathrm{g} / \mathrm{g})\end{array}$ & 0.47 & 0.61 & 0.02 & 0.46 \\
\hline
\end{tabular}

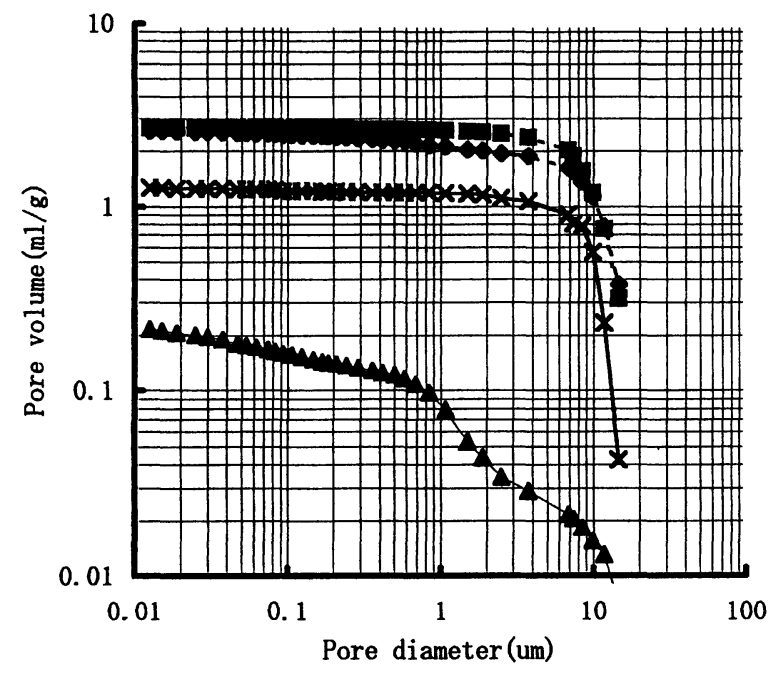

Fig. 3 Cumulative pore volume versus mean pore diameter for cedar chips $(-t)$, wood charcoals $(-)$ ), activated carbon $(-\mathcal{-})$ and kumazasa charcoals $(*)$

materials. Therefore, the water holding capacity of the cedar chips was the highest of these materials and it was the lowest in the case of the kumazasa charcoals in these materials.

The wastewater, which contained a high concentration of SS, was treated in this process. In order to effectively use the pore volume, the wastewater should be transported into the deep of the pores. Therefore, the pore volume constructed with a large diameter was needed. This pore volume functioned not only to prevent the formation of plug in the pores but also to be the habitat for the bacteria. Therefore, the effective pore volume (EP) was defined. It 
was constructed by the pore of which the diameter was larger than $10 \mu \mathrm{m}$. This pore volume was hypothesized to effectively absorb the water containing a high concentration of SS and to be the habitat of bacteria as the usual size of bacteria was approximately $1 \mu \mathrm{m}$. From the cumulative pore volumes of each materials shown in Fig. 3., the Eps were obtained and it is also shown in Table 4. In order to estimate whether the wastewater could be held in the medium and then be effectively treated or not, the EP/W ratio was defined. $\mathrm{EP} / \mathrm{W}$ ratio was the ratio of EP to water holding capacity (W). The $\mathrm{EP} / \mathrm{W}$ ratios of each materials were 0.47 (cedar chips), 0.61 (wood charcoal), 0.02 (activated carbon) and 0.45 (kumazasa charcoal), respectively. The high water holding capacity and $\mathrm{EP} / \mathrm{W}$ ratio means that the wastewater could be absorbed in this material and effectively treated. For example, the BOD and TOC removal efficiencies, by using wood charcoals as the medium, were the highest among these materials. The high water holding capacity and low $\mathrm{EP} / \mathrm{W}$ ratio means that the water could be absorbed but it could not be effectively treated. For example, the BOD and COD removal efficiencies were low in the case of the activated carbon.

Relationship among moisture content, water holding capacity, EP/W ratio and temperature increase When the overall heat transfer coefficient of the bioreactor was certain, in order to increase temperature in this process, there was minimum BOD load. In the case of the red bean processing wastewater, the temperature did not increase to higher than $50^{\circ} \mathrm{C}$ when the BOD load was lower than 3 $\mathrm{kg} \cdot \mathrm{m}^{-3} \cdot \mathrm{d}^{-1}{ }^{1)}$. Therefore, a certain amount of added wastewater should be held in the medium in order to keep the BOD load. Moisture content was used to estimate how much water was held in the medium. Usually, the unit of it was expressed by weight per weight as in the previous papers ${ }^{1,4,8}$. As the filling densities of the materials were quite different, this unit of the moisture content could not exactly express the absolute difference of water that existed in the material. It was necessary to use the moisture content expressed by weight per volume $(\% \mathrm{w} / \mathrm{v})$. Therefore, the absolute BOD load, calculated from the absolute water in the medium and BOD concentration, could be compared among different media. The moisture content $(\mathrm{w} / \mathrm{v})$ can be calculated according to equation (1) :

$$
\begin{array}{r}
\mathrm{MC}(\%)(\mathrm{w} / \mathrm{v})=100 \times(\mathrm{MC}(\mathrm{w} / \mathrm{w}) \times \text { Filling } \\
\text { density }) /(1-\mathrm{MC}(\mathrm{w} / \mathrm{w}))
\end{array}
$$

After adding the wastewater to the reactor, the moisture contents expressed by weight per weight were measured. Then the moisture contents, expressed by weight per volume, were calculated as shown in Table 5. The relationship among moisture content $(\% \mathrm{w} / \mathrm{v}), \mathrm{EP} / \mathrm{W}$ ratio, and temperature increase is shown in Fig. 4. From Fig. 4, the temperature in Run 4 was lower because the moisture content of kumazasa charcoal was lower, owing to the low water holding capacity in spite of the rather high $\mathrm{EP} / \mathrm{W}$ ratio. The temperature in Run 3 was also lower because the $\mathrm{EP} / \mathrm{W}$ ratio was too low in spite of the high moisture content (\% $\mathrm{w} / \mathrm{v}$ ) of the activated carbon.

According to moisture contents $(\% \mathrm{w} / \mathrm{v})$ and $\mathrm{EP} / \mathrm{W}$ ratios, the effective $\mathrm{BOD}$ loads, which was defined as the BOD existed in the effective pore volume in the media during the first day of the addition of wastewater, could be summarized and it is also shown in Table 5. It was obvious that the temperature did not increase when the activated carbon 
Table 5 Moisture content, EP/W ratio and effective BOD load in medium

\begin{tabular}{ccccc}
\hline Item & $\begin{array}{c}\text { Cedar } \\
\text { chips }\end{array}$ & $\begin{array}{c}\text { Wood } \\
\text { charcoals }\end{array}$ & $\begin{array}{c}\text { Activated } \\
\text { carbon }\end{array}$ & $\begin{array}{c}\text { Kumazasa } \\
\text { charcoals }\end{array}$ \\
\hline $\begin{array}{c}\text { Actual moisture } \\
\text { content (\%w/w) }\end{array}$ & 66 & 62 & 40 & 42 \\
\hline $\begin{array}{c}\text { Total water in } \\
\text { medium (kg) }\end{array}$ & 5.05 & 4.89 & 4.8 & 2.8 \\
\hline $\begin{array}{c}\text { Moisture } \\
\text { contentn (\%w/v) }\end{array}$ & 25.3 & 24.5 & 24 & 14 \\
\hline $\begin{array}{c}\mathrm{EP} / \mathrm{W} \text { ratio }(\mathrm{g} / \mathrm{g}) \\
\mathrm{Effectiv} \mathrm{BOD}\end{array}$ & 0.47 & 0.61 & 0.02 & 0.46 \\
$\mathrm{load}\left(\mathrm{kg} \cdot \mathrm{m}^{-3} \cdot \mathrm{d}^{-1}\right)$ & 4.27 & 5.37 & 0.17 & 2.31 \\
\hline
\end{tabular}

Note : effective $\mathrm{BOD}$ load $=($ total water in medium $* \mathrm{BOD} * \mathrm{EP} / \mathrm{W}$ ratio $) /$ Volume

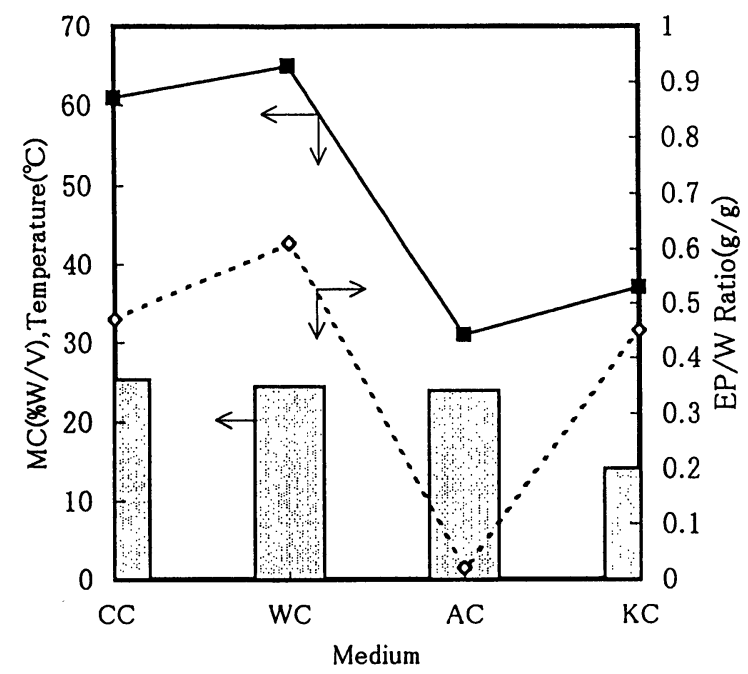

Fig. 4 Relationship among moisture content $(\square)$, EP/W rate $(\checkmark)$ and temperature increase ( - ) by using cdar chips (CC), wood charcoals (WC), activated carbon (AC) and kumazasa charcoals (KC) as medium

and kumazasa charcoals were used as media because of the low effective BOD load. Therefore, the first condition for the material to be a medium of the thermophilic oxic process was a high water holding capacity and the other condition was a high EP/W ratio. Based on the above results, the following equation (2) can be used to primarily select the medium for this process :
Effective BOD load $\left(\mathrm{kg} \cdot \mathrm{m}^{-3} \cdot \mathrm{d}^{-1}\right)=$ $\mathrm{MC}(\mathrm{w} / \mathrm{v}) \times \mathrm{BOD}(\mathrm{g} / l) \times \mathrm{EP} / \mathrm{W}>4$

The meaning of the units:

$\mathrm{w}$ : Weight of added wastewater $(\mathrm{kg})$ or volume of added wastewater $(l)$ in the medium (Density of the wastewater $\doteqdot 1 \mathrm{~kg} / l$ ) 
$\mathrm{v}$ : Volume of medium (l)

$\mathrm{g}:$ BOD quantity (g)

$l$ : Volume of added wastewater $(l)$

For example, the kumazasa charcoals could be a medium in this process to treat shochu processing wastewater ${ }^{2)}$ because the BOD of shochu processing wastewater was approximately $70,000 \mathrm{mg} / l$ and the calculated BOD load based on equation (2) was approximately $4.4 \mathrm{~kg} \cdot \mathrm{m}^{-3} \cdot \mathrm{d}^{-1}$. In other words, it was effective by using equation (2) for evaluation whether the material could be useful as a medium in this process or not when the wastewater containing a high concentration of BOD was applied.

Habitat of bacteria The new and used cedar chips were cut by a very sharp knife, and the section shape of a pore was observed by the SEM. The photo 5 shows the section shape of the new cedar chips. The photo 6 shows the mixture existed in the approximate $250 \mu \mathrm{m}$ deep of the pore after the cedar chips were used as a medium. This mixture was magnified and the large amount of bacteria and part of organic matter were observed as shown in photo 7 . This means that this kind of large pore volume can be a habitat of bacteria and that the organic matter in the pore can be effectively used by the bacteria. That was why the high BOD load could be applied in this process because the bacteria were not only attached on the surface of the medium but also existed in the pores of the medium. From another aspect, the size of the medium should be small because it was difficult for the bacteria to be found when the depth in the pore was larger than 250 $\mu \mathrm{m}$.

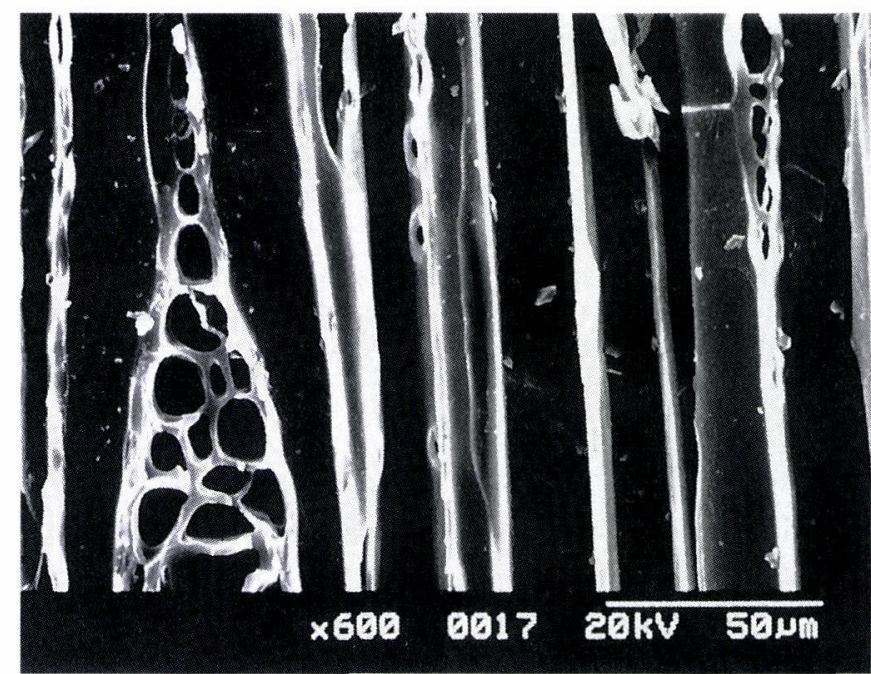

Photo 5 Cross section of cell of cedar chip in new 


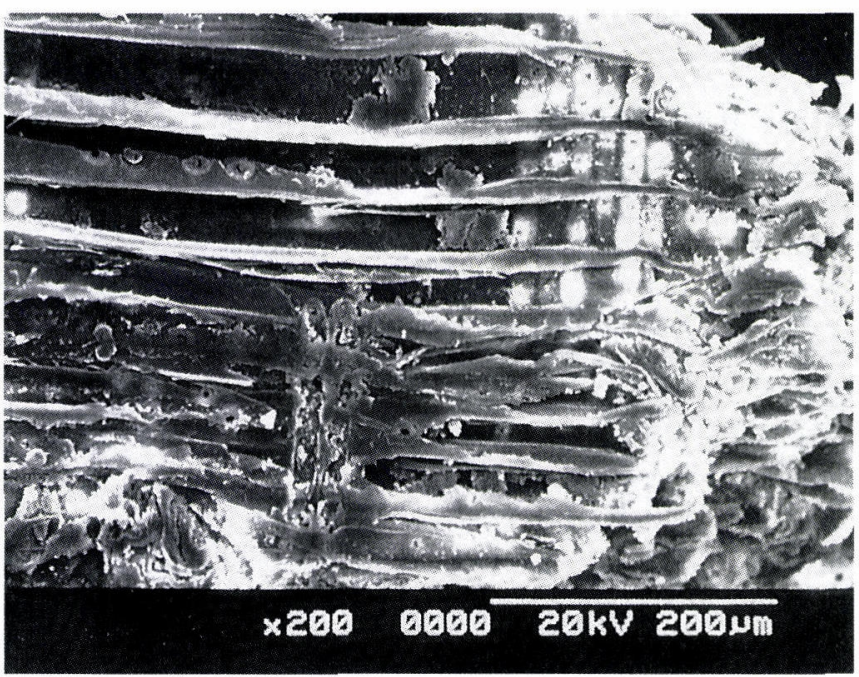

Photo 7 Cross section of cell of cedar chip in use

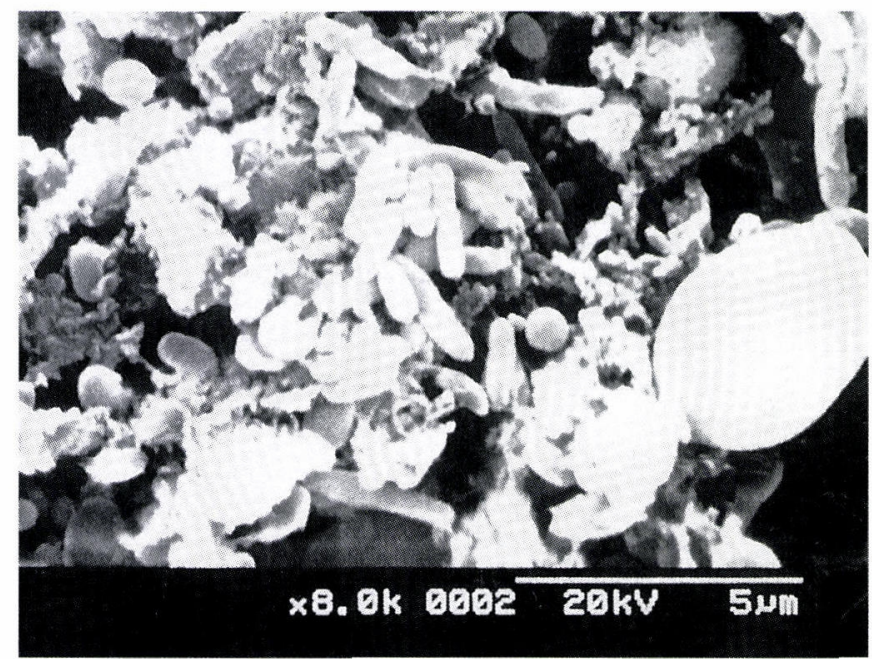

Photo 8 Bacteria and organic matter in magnified section

\section{SUMMARY}

The red bean processing wastewater was used to evaluate the characteristics of a medium needed for the thermophilic oxic process. In order to increase the temperature and treat the wastewater in a high BOD load, a high water holding capacity is necessary. The large $\mathrm{EP} / \mathrm{W}$ ratio was very important for the absorbed BOD to be effectively used by the bacteria and to be a habitat for them.

\section{ACKNOWLEDGMENTS}

The authors are grateful to Lieping $\mathrm{Zhu}$ for the help in conducting the experiment. 


\section{REFERENCES}

1 ) Liu B. G., Noda S. and Mori T. : Complete decomposition of organic matter in high BOD wastewater by thermophilic oxic process, Proc. Environ. Eng. Res. Japan., 29, 784 (1992)

2) Liu B. G. and Mori T. : Complete treatment of shochu processing wastewater by thermophilic oxic process, Proc. Environ. Eng. Res. Japan., 30, 165-174 (1993)

3 ) Liu B. G., Cai H. L. and Mori T. : Complete decomposition of swine wastes by thermophilic oxic process, Proc. Environ. Eng. Res. Japan., 31, 209-214 (1994) (In Japanese)

4) Cai H. L. and Mori T. : Complete treatment of thickened excess sludge by thermophilic oxic process, Proc. Environ. Eng. Res. Japan., 32, 371-277 (1995)

5 ) Inamori Y., Kong H. N. and Wu K. L., and Sudo R. : Significance and trend of advanced treatment of high strength of organic wastewater, Water and Waste, 37 (10), 7-16 (1995)

6 ) Mori T., Liu B. G., and Suk K. O. : Treatment of high strength of organic wastewater by thermophilic oxic process-complete decomposition and evaporation -, Chemical Industry, Japan, 44 (11), 52-58 (1993)

7 ) Mori T., Narita A., Amimoto T. And Chino M. : Composting of municipal sewage sludge mixed with rice hulls, Soil Sci. Plant Nutr., 27 (4), 477-486 (1981)

8 ) Nakasaki K. : Effect of temperature on composting of sewage sludge, Appl. And Environ. Microbiol., 50 (6), 15261530 (1985)

9 ) Liu B. G. and Mori T. : Formation of a minute amount of excess sludge in the treatment of high strength organic wastewater by thermophilic oxic process, Jap. J. Wat. Treat. Biol., 32 (1), 41-49 (1996)

(Submitted 1997. 4.7) (Accepted 1997. 8. 20) 